\title{
Respon Siswa Terhadap Pembelajaran Dalam Jaringan (Daring) Pada Mata Pelajaran Matematika
}

\author{
Denny Andriani ${ }^{\mathrm{a}, 1^{*}}$, Krisdianto Hadi Prasetyo ${ }^{\mathrm{a}, 2}$, Erika Laras Astutiningtyas ${ }^{\mathrm{a}, 3}$ \\ a Pendidikan Matematika, Universitas Veteran Bangun Nusantara, Sukoharjo, Indonesia \\ ${ }^{1}$ dennyandrn@gmail.com*; ${ }^{*}$ krisdianto_prasetyo@yahoo.co.id; ${ }^{3}$ astutiningtyas.univet@gmail.com \\ * Corresponding Author
}

Diterima 14 August 2020; Disetujui 21 Februari 2021; Diterbitkan 22 Februari 2021

\begin{abstract}
The objective of this study is to determine students' responses to learning in the network (online) in mathematics. This research uses a descriptive method with a qualitative approach. Data collection technique is questionnaire. The questionnaire consisted of positive and negative statements totaling 20 statements. The questionnaire is distributed via Googleform. Data analysis techniques are data reduction, data presentation and conclusion. The subjects are 29 students of Class XI MIPA 1 of SMA Negeri 1 Weru in the academic year $2019 / 2020$. The result shows that the average percentage of student responses in mathematics received positive criteria. With the average percentage of students' responses to the first indicator, namely interest of $83.62 \%$ so it is included in the positive criteria. In the second indicator, motivation is $74.14 \%$ so it is included in the positive criteria. The third indicator is satisfaction at $80.17 \%$ so it is included in the positive criteria. In the fourth indicator, interest is $73.49 \%$ so it is included in the positive criteria. And the fifth indicator is the response of $75.43 \%$ so it is included in the positive criteria.
\end{abstract}

KEYWORDS

Student Response Online Learning Mathematics

This is an openaccess article under the CC-BY-SA license

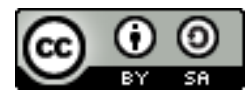

\section{Pendahuluan}

Meningkatnya virus corona di Indonesia membuat pemerintah mengeluarkan berbagai imbauan, peraturan dan kebijakan yang diberikan kepada masyarakat seluruh Indonesia. Pemerintah Indonesia berusaha terus untuk memutus rantai persebaran virus corona dengan membuat berbagai kebijakan diantaranya PSBB (Pembatasan Sosial Berskala Besar), Physical Distancing dan pemberlakuan WFH (Work From Home). Disaat kondisi pandemi covid-19, aktivitas menjadi terbatas. Pemerintah menyarankan semua kegitan diluar rumah dibatasi. Pemerintah menerapkan kebijakan belajar, dari rumah, bekerja dari rumah dan ibadah dirumah. Hal ini dilakukan untuk meminimalisir keadaan yang mulai memburuk saat ini. Dampak dari virus corona ini sudah memasuki dunia pendidikan. Pemerintah mengeluarkan kebijakan untuk meliburkan seluruh lembaga pendidikan. Hal ini dilakukan sebagai upaya pencegahan persebaran virus corona.

Model pembelajaran yang dilakukan oleh guru harus memperhatikan tujuan yang ingin dicapai, kemampuan dan latar belakang siswa, kemampuan dan latar belakang guru, keadaan proses belajar yang sedang berlangsung dan alat-alat atau saran prasarana yang tersedia (Ulfa, Maria. 2018). Ditambahkan oleh (Hidayat 2011) bahwa model pembelajaran terbaik adalah yang paling sesuai dengan karakteristik peserta didik, tujuan, materi ajar, media, waktu yang disediakan dan situasi juga kondisi saat ini. Oleh karena itu, pemerintah membuat kebijakan agar siswa tetap masih bisa belajar dengan kondisi saat ini. Pemerintah membuat kebijakan bahwa proses belajar mengajar dilaksanakan dirumah melalui pembelajaran jarak jauh atau secara daring. Pembelajaran dalam jaringan (daring) menjadi salah satu alternatif dalam pembelajaran saat ini. Pembelajaran ini dilakukan dengan memanfaatkan jaringan internet. Pembelajaran ini sebagai pengganti pembelajaran tatap muka disekolah, sehingga guru dan siswa tetap bisa melaksanakan proses belajar mengajar.

Pembelajaran dalam jaringan (daring) ini juga dilakukan pada mata pelajaran matematika. Pemahaman tentang ide atau gagasan matematika yang dimiliki seseorang memiliki manfaat dalam menyelesaikan suatu masalah dalam kehidupannya, sehingga penting bagi manusia untuk 
mempelajari matematika (Kuncorowati, Mardiyana, and Saputro 2017; Hidayah et al. 2018). Di sisi lain, banyak siswa yang saat ini memberikan respon negatif terhadap matematika sebagai dampak dari anggapannya bahwa matematika merupakan mata pelajaran yang paling sulit (Zakiah, Prasetyo, and Astutiningtyas 2019).

Melihat kondisi yang saat ini mengharuskan pembelajaran dilaksanakan secara daring, maka semua pendidik di Indonesia berpikir keras untuk membuat pembelajaran matematika tetap berkualitas. Hal ini sesuai pendapat (Styawan, Susilowati, and Wulandari 2019) bahwa pendidikan yang diterapkan harus selalu dilakukan pembaharuan untuk meningkatkan kualitas pendidikan suatu bangsa. Pandemi covid-19 yang telah melanda Indonesia di awal tahun 2020 memaksa semua civitas akademika untuk memanfaatkan teknologi secara maksimal dalam pembelajaran. Sesuai dengan pernyataan (Imania and Bariah 2019) bahwa penggunaan e-learning sebagai media pembelajaran, diharapkan dapat meningkatkan daya serap dari siswa atas materi yang diajarkan, meningkatkan partisipasi aktif dari siswa, meningkatkan kemampuan belajar mandiri dan kemampuan menampilkan informasi dengan perangkat teknologi informasi.

Berdasarkan hasil informasi yang didapat dari beberapa siswa, guru memberikan materi pelajaran matematika melalui beberapa pembelajaran dalam jaringan (daring). Seperti google classroom, google form, media sosial (group whatsapp, email,dan lain-lain). Hal ini membuat siswa memberikan tanggapan atau respon kepada guru terkait dengan pembelajaran dalam jaringan (daring) ini. Respon siswa terhadap pembelajaran dalam jaringan (daring) ini merupakan sesuatu yang sangat penting untuk diketahui dalam upaya pengembangan proses berfikir siswa terhadap pembelajaran (Hasan 2017).

Beberapa penelitian mengenai respon siswa terhadap pembelajaran daring telah dilakukan. Salah satunya adalah (Kurniawati 2011) yang melakukan penelitian dengan judul "Respons Siswa MTSN 1 Jakarta Terhadap Pemanfaatan Situs www.alsofwah.or.id". Dapat disimpulkan dengan menfaatkan situs www.alsofwah.or.id mendapatkan respon yang positif. Dan adapun dari hasil respon kognitif dengan skor sebesar 871 dan mean sebesar 29,03\%, sedangkan respon afektif dengan skor sebesar 878 dan mean sebesar $29,7 \%$. Berdasarkan uraian diatas, peneliti tertarik untuk melakukan penelitian tentang respon siswa terhadap pembelajaran dalam jaringan(daring) pada mata pelajaran matematika. Penelitian ini bertujuan untuk mengetahui respon siswa terhadap pembelajaran dalam jaringan (daring) pada mata pelajaran matematika.

\section{Metode}

Penelitian yang dilakukan menggunakan penelitian deskriptif, dengan menggunakan pendekatan penelitian kualitatif. Penelitian ini bersifat deskriptif karena bertujuan untuk membuat deskripsi tentang respon siswa terhadap pembelajaran dalam jaringan (daring) pada mata pelajaran matematika di kelas XI MIPA SMA Negeri 1 Weru. Adapun pendekatan kualitatif dalam penelitian ini menghasilkan data deskriptif berupa tulisan naratif mengenai respon siswa terhadap pembelajaran dalam jaringan (daring) pada mata pelajaran matematika di kelas XI MIPA SMA Negeri 1 Weru. Penelitian dilaksanakan di SMA Negeri Weru yang terletak di Desa Karangtengah, Kecamatan Weru, Kabupaten Sukoharjo, Provinsi Jawa Tengah. Penelitian dilaksanakan pada tanggal 2 Juni 2020 - 10 Juni 2020.

Adapun subjek penelitian dalam penelitian ini adalah siswa kelas XI MIPA 1 di SMA Negeri 1 Weru dengan jumlah 29 siswa. Pengambilan subjek penelitian menggunakan purposive sampling. Subjek diambil berdasarkan atas saran dan pertimbangan dari guru mata pelajaran matematika di kelas XI MIPA SMA Negeri 1 Weru.

Sumber data penelitian terdiri dari dua data yaitu data primer dan data sekunder. Data primer adalah data yang diperoleh langsung dari responden yang didapat dari angket. Dalam hal ini peneliti memberikan angket atau daftar pertanyaan yang disampaikan kepada responden untuk diisi. Untuk mengetahui respon siswa kelas XI MIPA 1 SMA Negeri 1 Weru terhadap pembelajaran dalam jaringan (daring) pada mata pelajaran matematika akan diukur dengan skala likert. Adapun skala likert ini menggunakan 4 skala penilaian yaitu SS (Sangat Setuju), S (Setuju), TS (Tidak Setuju), dan STS (Sangat Tidak Setuju). Sedangkan data sekunder adalah data yang dikumpulkan peneliti berupa jurnal-jurnal, buku-buku serta sumber lainnya yang berkaitan dengan masalah penulisan 
penelitian ini dan hasil wawancara dengan guru mata pelajaran matematika dikelas XI MIPA SMA Negeri 1 Weru.

Teknik pengumpulan data yang digunakan dalam penelitian ini berupa angket respon siswa. Angket digunakan untuk mengetahui respon siswa terhadap pembelajaran dalam jaringan (daring) pada mata pelajaran matematika.

Angket yang digunakan dalam penelitian ini terdiri dari 5 indikator yaitu ketertarikan, motivasi, kepuasan, minat dan tanggapan (Nurlatipah, Juanda, and Maryuningsih 2015). Angket terdiri dari pertanyaan positif dan negatif. Adapun angket yang digunakan berupa angket tertutup berbentuk skala likert dengan 4 skala penilaian yaitu SS (Sangat Setuju) bernilai 4, S (Setuju) bernilai 3, TS (Tidak Setuju) bernilai 2, dan STS (Sangat Tidak Setuju) bernilai 1.

Analisis data yang digunakan dalam penelitian ini adalah reduksi data, penyajian data, dan penarikan kesimpulan. Reduksi data yang dilakukan dalam penelitian ini adalah merangkum, memilih data yang pokok, menyederhanakan, melakukan pengkodean dan membuang hal-hal yang tidak perlu. Reduksi dilakukan pada hasil angket respon siswa (Purwaningrum 2016; Arikunto 2013).

Menurut (Nunung 2019), Langkah-langkah analisis data respon siswa dimulai dengan membuat skor setiap pilihan jawaban dengan menggunakan skala Likert. Skor angket respon siswa mengacu pada Tabel 1.

Tabel 1. Skor Angket Respon Siswa

\begin{tabular}{ccc}
\hline $\begin{array}{c}\text { Kategori Jawaban } \\
\text { Siswa }\end{array}$ & \multicolumn{2}{c}{ Skor untuk Penyataan } \\
& Positif & Negatif \\
\hline SS (Sangat Setuju) & 4 & 1 \\
S (Setuju) & 3 & 2 \\
TS (Tidak Setuju) & 2 & 3 \\
STS (Sangat Tidak & 1 & 4 \\
Setuju) & & \\
\hline
\end{tabular}

Langkah selanjutnya adalah menghitung skor total tiap-tiap item dan menghitung persentase perolehan skor total per item. Rumus yang digunakan sebagai berikut:

$$
\text { PNRS }=\frac{\sum_{i=1}^{n} N R S}{\text { NRS maksimum }} \times 100 \%
$$

dengan PNRS adalah Persentase Nilai Respon Siswa, $\sum N R S=$ Total Nilai Respon Siswa pada setiap item pernyataan dan NRS maks $=\mathrm{n} x$ skor pilihan terbaik, dengan $\mathrm{n}$ adalah banyaknya seluruh responden. Langkah terakhir adalah menentukan kategori persentase respon siswa sesuai Tabel 2 (Lukitawati 2014).

Tabel 2. Kategori Persentase Respon Siswa

\begin{tabular}{cc}
\hline $\begin{array}{c}\text { Persentase Respon } \\
\text { Siswa }\end{array}$ & Kategori \\
\hline $85 \% \leq \mathrm{NRS}$ & Sangat \\
$70 \% \leq \mathrm{NRS}<85 \%$ & Positif \\
$50 \% \leq \mathrm{NRS}<70 \%$ & Positif \\
Kurang \\
$<50 \%$ Setuju $)$ & Positif \\
\hline
\end{tabular}

Setelah data direduksi, maka langkah berikutnya adalah penyajian data. Data hasil angket respon siswa disajikan dalam bentuk deskripsi. Melalui penyajian data tersebut, data akan semakin mudah untuk dipahami. Langkah terakhir dalam analisis data adalah penarikan kesimpulan. Kesimpulan ini di buat berdasarkan hasil analisis data angket respon siswa. 
Data yang dikumpulkan tidak selamanya mengandung unsur kebenaran. Oleh karena itu, diperlukan validitas data dalam penelitian ini. Validitas data pada penelitian ini menggunakan cara triangulasi. Triangulasi adalah teknik pemeriksaan keabsahan data yang memanfaatkan sesuatu(data) yang lain diluar data yang telah diperoleh untuk keperluan pengecekan atau sebagai pembanding (Widodo 2013)

Triangulasi yang digunakan dalam penelitian ini adalah triangulasi sumber yaitu mengkonfirmasikan data yang diperoleh dari suatu sumber dengan sumber lainnya dengan cara membandingkannya lalu dianalisis sehingga menghasilkan kesimpulan. Sumber yang digunakan pada triangulasi ini adalah guru mata pelajaran matematika di kelas XI MIPA SMA Negeri 1 Weru, dengan cara mewawancarai guru tersebut menggunakan pertanyaan-pertanyaan yang sesuai dengan isi dari angket respon siswa. Hasil dari data wawancara tersebut dapat dibandingkan dengan hasil penelitian. Dari hasil perbandingan tersebut dapat menghasilkan kesimpulan.

Menurut (Arikunto 2013), prosedur penelitian yang dilakukan terbagi menjadi 3 tahap, yaitu.

\subsection{Pembuatan Rancangan Penelitian}

Ada beberapa hal yang harus disiapkan peneliti sebelum melaksanakan penelitian. Pada tahap ini peneliti terlebih dauhulu menyusun proposal penelitian, lalu melakukan perbaikan proposal penelitian berdasarkan hasil konsultasi dengan pembimbing, menyiapkan surat ijin penelitian serta penyusunan instrumen penelitian yang berupa angket respon siswa terhadap pembelajaran dalam jaringan (daring).

\subsection{Pelaksanaan Penelitian}

Pada tahap ini peneliti akan melaksanakan penelitian dengan metode yang sudah direncanakan. Pada tahap ini, peneliti membagikan angket respon kepada siswa.

\subsection{Pembuatan Laporan Penelitian.}

Berdasarkan data yang diperoleh dari angket yang diberikan kepada siswa secara keseluruhan akan dianalisis untuk ditarik kesimpulannya. Kemudian peneliti konsultasi laporan penelitian dengan pembimbing dan melakukan perbaikan laporan penelitian berdasarkan hasil konsultasi dengan pembimbing.

\section{Hasil dan Pembahasan}

Penelitian ini bertujuan untuk mengetahui respon siswa terhadap pembelajaran daring pada mata pelajaran matematika. di SMAN 1 Weru. Data angket respon siswa diperoleh dari kelas XI MIPA 1 yang berjumlah 29 siswa. Selanjutnya responden mengisi angket sebanyak 20 butir pertanyaan dengan 4 alternatif jawaban yaitu SS (Sangat Setuju), S (Setuju), TS (Tidak Setuju), STS (Sangat Tidak Setuju). Angket yang digunakan dalam penelitian ini terdiri dari 5 indikator yaitu ketertarikan, motivasi, kepuasan, minat dan tanggapan. Adapun hasil respon siswa di kelas XI MIPA 1 SMAN 1 Weru dapat dilihat pada tabel 3.

Tabel 3. Rata-Rata Persentase Respon Siswa Terhadap Pembelajaran Daring Pada Mata Pelajaran Matematika.

\begin{tabular}{cccc}
\hline No & Indikator & $\begin{array}{c}\text { Rata-Rata } \\
\text { Persentase } \\
\text { Respon } \\
\text { Siswa }\end{array}$ & $\begin{array}{c}\text { Kriteria } \\
\text { Respon }\end{array}$ \\
\hline 1. & Ketertarikan & $83,62 \%$ & Positif \\
2. & Motivasi & $74,14 \%$ & Positif \\
3. & Kepuasaan & $80,17 \%$ & Positif \\
4. & Minat & $73,49 \%$ & Positif \\
5. & Tanggapan & $75,43 \%$ & Positif \\
\hline
\end{tabular}

Tabel 3 menunjukkan bahwa rata-rata respon siswa SMA Negeri 1 Weru dikela XI MIPA 1 terhadap pembelajaran daring pada mata pelajaran matematika pada indikator ketertarikan, motivasi, kepuasaan, minat, dan tanggapan mendapat kriteria positif. Hal ini menunjukkan bahwa pembelajaran daring pada mata pelajaran matematika ini mendapat respon yang positif dari siswa. 
Gambar 1 menunjukkan bahwa indikator ketertarikan, motivasi, kepuasaan, minat dan tanggapan mendapatkan respon yang positif.

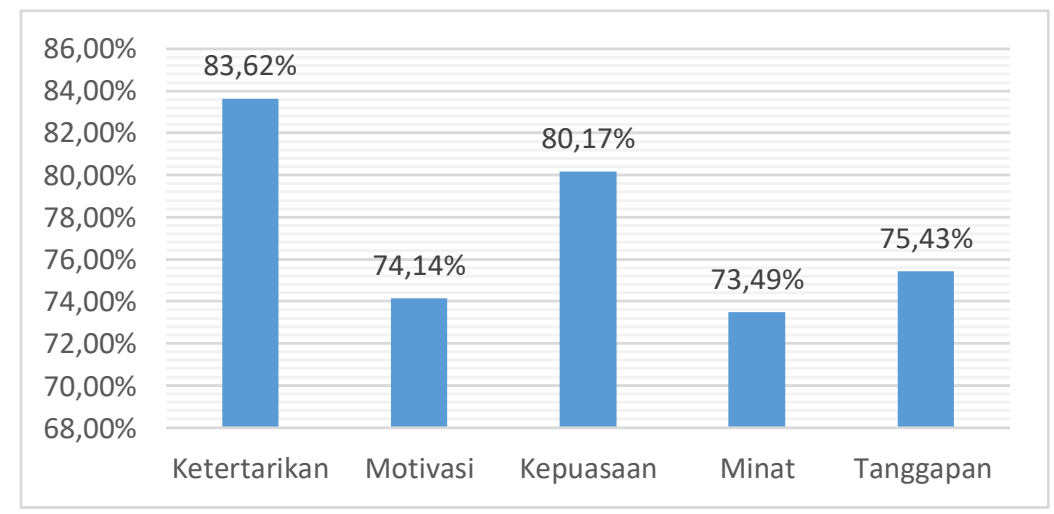

Gambar 1. Hasil Analisis Respon Siswa SMAN 1 Weru

Pada indikator ketertarikan rata-rata persentase respon siswa sebesar 83,62\% dengan kriteria positif. Hal ini menunjukkan bahwa dengan pembelajaran daring ini membuat siswa memberi perhatian lebih pada pembelajaran daring ini. Dengan guru memanfaatkan jaringan internet, membuat siswa menjadi lebih tertarik dalam proses pembelajaran yang dilakukan saat ini. Menurut (Meidawati 2019) yang mengungkapkan bahwa setelah mengikuti pembelajaran berbasis daring learning, para siswa semakin semangat mengikuti pembelajaraan dan siswa tidak merasa bosan saat pembelajaran daring. Siswa juga tertarik saat menggunakan pembelajaran berbasis daring learning dibanding dengan metode konvensional (ceramah).

Respon yang positif dengan rata-rata $74,14 \%$ pada indikator motivasi diperoleh karena pembelajaran daring ini membuat siswa menjadi termotivasi dalam belajar. Motivasi belajar siswa dapat dilihat dari reaksi positif terhadap stimulus yang diberikan oleh guru dengan menunjukkan semangat dalam menyelesaikan tugas belajarnya. Motivasi berfungsi sebagai pendorong usaha serta pencapaian prestasi. Menurut (Tigowati, Efendi, and Budiyanto 2017) Motivasi yang baik akan menunjukkan hasil yang baik pula. Hasil belajar akan menjadi optimal akan menjadi optimal kalau ada motivasi. Makin tepat motivasi yang diberikan, akan makin berhasil pula pelajaran. Jadi motivasi menentukan intensitas usaha belajar bagi para siswa

Kepuasan adalah perasaan senang siswa dalam mengikuti pembelajaran. Rata-rata persentase kepuasaan dalam pembelajaran daring ini sebesar $80,17 \%$ dengan kriteria positif. Hal ini menunjukkan bahwa pembelajaran daring ini menimbulkan perasaan senang kepada siswa dalam pengalaman pembelajaran mereka. Siswa merasa pembelajaran ini menjadi lebih menyenangkan karena dapat berdiskusi dengan guru dan dapat bertukar pikiran dengan siswa lainnya sehingga dapat menyelesaikan tugas-tugas yang diberikan oleh guru. Menurut (Yasir, Suarman, and Gusnardi 2017) Seorang siswa dapat dianggap puas jika siswa merasa bahwa pelajaran dapat memenuhi kebutuhan dan harapannya. Hal ini dapat memotivasi siswa untuk berupaya lebih dalam kegiatan pembelajaran, meningkatkan sikap positif terhadap pelajaran.

Minat adalah perasaan yang mendorong siswa untuk melakukan kegiatan belajar. Rata-rata persentase minat dalam pembelajaran daring ini sebesar $73,49 \%$ dengan kriteria positif. Hal ini menunjukkan bahwa pembelajaran daring ini membuat siswa memiliki kemauan untuk belajar sehingga dapat mencapai hasil belajar yang optimal. Semakin baik minat belajar siswa terhadap pelajaran matematika, maka semakin mudah kegiatan belajar dan hasil belajar juga akan semakin baik. Menurut (Rusmiati 2017) Minat dalam proses belajar mengajar merupakan salah satu faktor yang besar pengaruhnya terhadap prestasi belajar. Siswa yang minat belajarnya tinggi akan memperoleh prestasi belajar yang baik.

Respon yang positif pula juga dengan rata-rata $75,43 \%$ pada indikator tanggapan diperoleh karena pembelajaran ini dianggap menjadi pembelajaran yang efektif untuk kondisi saat ini. Karena pembelajaran daring ini lebih menghemat dalam waktu dan tenaga. Siswa dapat menjadi lebih 
kreatif dalam belajar secara mandiri. Dengan pembelajaran ini, membuat siswa lebih mudah berinteraksi dengan guru sehingga siswa dapat menjadi lebih semangat dalam belajar.

\section{Simpulan}

Berdasarkan hasil perhitungan dan analisis data yang telah dilakukan, dapat disimpulkan bahwa respon siswa terhadap pembelajaran daring pada mata pelajaran matematika di kelas XI MIPA SMA Negeri 1 Weru tahun ajaran 2019/2020 mendapat respon yang positif. Persentase rata-rata respon siswa dengan indikator pertama yaitu ketertarikan siswa terhadap pembelajaran daring sebesar $83,62 \%$ sehingga termasuk dalam kriteria positif. Pada indikator kedua yaitu motivasi siswa dalam belajar selama pembelajaran daring ini sebesar $74,14 \%$ sehingga termasuk dalam kriteria positif. Pada indikator ketiga yaitu kepuasaan siswa selama pembelajaran daring ini sebesar $80,17 \%$ sehingga termasuk dalam kriteria positif. Pada indikator keempat yaitu minat siswa dalam belajar selama pembelajaran daring sebesar $73,49 \%$ sehingga termasuk dalam kriteria positif. Dan indikator kelima yaitu tanggapan siswa selama pembelajaran daring sebesar $75,43 \%$ sehingga termasuk dalam kriteria positif.

\section{Referensi}

Arikunto, Suharsimi. 2013. Prosedur Penelitian Suatu Pendekatan Praktik. Jakarta: PT. Rineka Cipta.

Hasan, Buaddin. 2017. "Karakteristik Respon Siswa Dalam Menyelesaikan Soal Geometri Berdasarkan Taksonomi SOLO.” JINoP (Jurnal Inovasi Pembelajaran) 3 (1): 449. https://doi.org/10.22219/jinop.v3i1.4282.

Hidayah, Nikken Isnaini, Vina Dwi Riski, Lela Kumalasari, and Erika Laras Astutiningtyas. 2018. "Pengaruh Penggabungan Metode Outdoor Dengan Indoor Learning Menggunakan Sistem Sepur Selam.” Jurnal Math Educator Nusantara: Wahana Publikasi Karya Tulis Ilmiah Di Bidang Pendidikan Matematika 4 (2): 168. https://doi.org/10.29407/jmen.v4i2.12187.

Hidayat, Kholiq. 2011. "Penggunaan Model Pembelajaran Reciprocal Untuk Meningkatkan Ketrampilan Passing Bawah Permainan Bola Voli Mini Pada Siswa Kelas V Sekolah Dasar Negeri Sinomwidodo 02 Kabupaten Pati Tahun Pelajaran 2010/2011.” Universitas Negeri Semarang. httplib.unnes.ac.id7133110407a.pdf.

Imania, Kuntum Annisa, and Siti Khusnul Bariah. 2019. "Rancangan Pengembangan Instrumen Penilaian Pembelajaran Berbasis Daring.” Jurnal Petik 5 (1): 31-47. https://doi.org/10.31980/jpetik.v5i1.445.

Kuncorowati, R H, Mardiyana Mardiyana, and D R S Saputro. 2017. "The Analysis of Student's Difficulties Based on Skemp's Understanding Theorem at The Grade VII in Quadrilateral Topic." International Journal of Science and Applied Science: Conference Series 2 (1): 318. https://doi.org/10.20961/ijsascs.v2i1.16736.

Kurniawati, Eka. 2011. "Respons Siswa MTSN 1 Jakarta Terhadap Pemanfaatan Situs Www. AlSofwah .or.Id." http://repository.uinjkt.ac.id/dspace/handle/123456789/2886.

Lukitawati, Prima (UNIKAL). 2014. "Pengembangan Media Pembelajaran Matematika Berbasis ICT (Information and Communication Technology) Melalui Pendekatan SAVI (Somatic, Auditory, Visual, and Intellectual) Pada Materi Geometri Transformasi Kelas VII Di SMP Ma'had Islam Pekalongan.” Delta: Jurnal Ilmiah Pendidikan Matematika 2 (2): 42-50. http://jurnal.unikal.ac.id/index.php/Delta/article/view/433/395.

Meidawati, Sobron A.N, Bayu, Rani,. 2019. "Persepsi Siswa Dalam Studi Pengaruh Daring Learning Terhadap Minat Belajar Ipa." SCAFFOLDING: Jurnal Pendidikan Islam Dan Multikulturalisme 1 (2): 30-38. https://doi.org/10.37680/scaffolding.v1i2.117.

Nunung, Valentina. 2019. "Respon Siswa Terhadap Modul Pembelajaran Berbasis Savi (Somatic, Auditory, Visualitation, Intellegency) Pada Materi Ekosistem Di Sman 1 Papar.” Jurnal 
Biologi Dan Pembelajarannya (JB\&P) 6 (1): 36-38. https://doi.org/10.29407/jbp.v6i1.12896.

Nurlatipah, Nunik, Anda Juanda, and Yuyun Maryuningsih. 2015. "Pengembangan Media Pembelajaran Komik Sains Yang Disertai Foto Untuk Meningkatkan Hasil Belajar Siswa Kelas Vii Smpn 2 Sumber Pada Pokok Bahasan Ekosistem.” Jurnal Scientiae Educatia 5 (2): $1-13$.

Purwaningrum, Jayanti Putri. 2016. "RESPON SISWA SD TERHADAP PEMBELAJARAN PENEMUAN BERBANTUAN ALAT PERAGA PADA MATERI VOLUM BALOK DAN KUBUS.” PENDAS: Jurnal Ilmiah Pendidikan Dasar 1 (1). https://journal.unpas.ac.id/index.php/pendas/article/view/193.

Rusmiati. 2017. "Pengaruh Minat Belajar Terhadap Prestasi Belajar Bidang Studi Ekonomi Siswa Ma Al Fattah Sumbermulyo." Jurnal Ilmiah Pendidikan Dan Ekonomi 1 (1): 21-36. http://journal.stkipnurulhuda.ac.id/index.php/utility.

Styawan, Sili Wijak, Dewi Susilowati, and Andhika Ayu Wulandari. 2019. "Pengaruh Model Pembelajaran Kooperatif Tipe Snowball Throwing Terhadap Prestasi Belajar Matematika." ABSIS: Mathematics Education Journal 1 (1). https://doi.org/10.32585/absis.v1i1.308.

Tigowati, Tigowati, Agus Efendi, and Cucuk W Budiyanto. 2017. "E-Learning Berbasis Schoology Dan Edmodo: Ditinjau Dari Motivasi Dan Hasil Belajar Siswa Smk." Elinvo (Electronics, Informatics, and Vocational Education) 2 (1): 49-58. https://doi.org/10.21831/elinvo.v2i1.16416.

Ulfa, Maria., Saifuddin. 2018. "Terampil Memilih Dan Menggunakan Metode Pembelajaran." Suhuf 30 (1): 35-56.

Widodo, Sri Adi. 2013. "Analisis Kesalahan Dalam Pemecahan Masalah Divergensi Tipe Membuktikan Pada Mahasiswa Matematika.” Jurnal Pendidikan Dan Pengajaran 46 (2): 106-13.dodok_chakep@yahoo.com.

Yasir, Muhammad, Suarman, and Gusnardi. 2017. "Analisis Tingkat Kepuasan Siswa Dan Motivasi Dalam Pembelajaran Kelompok (Cooperative Learning) Dan Kaitannya Dengan Hasil Belajar Akuntansi Di SMK Labor Binaan FKIP UNRI Pekanbaru." Jurnal Pekbis Volume 9 (2): 77-90. https://www.google.com/search?safe=strict\&client=firefox$\mathrm{b} \& \mathrm{ei}=\mathrm{Ytt} 0 \mathrm{~W}-$

34Dsqe9QPukIioCA\&q=Analisis+Tingkat+Kepuasan+Siswa+dan+Motivasi+Dalam+Pembel ajaran+Kelompok+(Cooperative+Learning $)+$ dan+Kaitannya+Dengan+Hasil+Belajar+Akunta nsi+di+SMK+Labor+Binaan+FKIP+UN.

Zakiah, Ifa Roselina, Krisdianto Hadi Prasetyo, and Erika Laras Astutiningtyas. 2019. "Meningkatkan Aktivitas Dan Hasil Belajar Melalui Pembelajaran Kooperatif Tipe Make a Match." ABSIS: Mathematics Education Journal 1 (2). https://doi.org/10.32585/absis.v1i2.362. 